\title{
QUALITY MALAYSIAN ENGLISH LANGUAGE TEACHERS: EXAMINING A POLICY STRATEGY
}

\author{
Napisah Kepol \\ Faculty of Languages and Communication \\ Universiti Pendidikan Sultan Idris, Malaysia \\ napisah.kepol@fbk.upsi.edu.my
}

\begin{abstract}
Purpose - The purpose of this paper is to examine and discuss one of the strategies in the latest Malaysian language education policy Memartabatkan Bahasa Malaysia Memperkukuh Bahasa Inggeris (MBMMBI) (To Uphold Bahasa Malaysia and to Strengthen the English Language). The strategy in focus is aimed at improving the quality of English language teachers. This strategy is examined in light of selected research findings and other information that is deemed relevant to a beneficial discussion of the topic.
\end{abstract}

Methodology - The method employed was document analysis which involved intensive reading of the Malaysian Ministry of Education information booklets about the MBMMBI policy and other related documents and resources providing supplementary information about the policy.

Findings - The analysis showed that of the five sub-strategies proposed in the main strategy targeted at improving the quality of English language teachers, three of them addressed the commonly included aspects of knowledge, skills and abilities found in the definitions of teacher quality in the literature. Teacher disposition and evaluation, another two aspects often related to teacher quality, were not included.

Conclusion - Quality was not featured consistently in the policy strategy analysed. Overall, the policy did not capture the full complexity of the concept of teacher quality. Whether the omission of the other attributes of teacher quality has had any effect on the 
aspirations of the policy remained to be seen. Follow-up strategies were suggested such as monitoring, evaluation, reinforcement, and support strategies to ensure that the policy in practice would have the desired impact as envisaged by the policy makers.

Significance - The quality of teachers has frequently been linked to student achievement in schools. This association between teacher quality and student achievement provides reason for an examination and discussion of the topic of research conducted in this paper. It is also hoped that this paper will provide some impetus for further discussions of English language teacher quality in the current Malaysian educational context.

Keywords: Language education policy, strategy, English language teachers, teacher quality.

\section{INTRODUCTION}

In 2010, the Malaysian Ministry of Education announced a new language education policy. The main intention of this policy was to strike the right balance in the Malaysian education system between the importance placed on the national language, Bahasa Malaysia, and that of the official second language, English. The new language education policy known by its widely-used Malay acronym MBMMBI (Memartabatkan Bahasa Malaysia dan Memperkukuh Bahasa Inggeris), and its English translation as 'To Uphold Bahasa Malaysia and to Strengthen the English Language' was introduced to replace the previous policy called the 'Teaching and Learning of Science and Mathematics in English' (more commonly referred to by its Malay acronym, PPSMI (Pengajaran dan Pembelajaran Sains dan Matematik dalam Bahasa Inggeris)). The PPSMI policy, which was in force from 2003 to 2010, involved a change in the medium of instruction from Bahasa Malaysia to English in the teaching of Science and Mathematics subjects at the primary and secondary levels of education. This change in the medium of instruction provided students at both the primary and secondary levels of education with additional exposure to the English language through the two subjects. Although restricted to English for specific purposes, the change had meant more teaching and learning time not 
only in the English language, but also for its special purpose use in Science and Mathematics.

The introduction of the new MBMMBI policy reinstated Bahasa Malaysia as the medium of instruction for the Science and Mathematics subjects at both the primary and secondary levels of education. The previous policy, PPSMI, had been deemed as not being able to achieve its goal of improving the levels of student achievement in the two subjects, especially students in the rural areas. One of the reasons, among the many reported (MOE, n.d.a), for this lack of success, had been the inadequate level of proficiency in English among the teachers teaching the two subjects. Under the PPSMI policy, teachers would have to combine their knowledge of the subject matter (Science or Mathematics) with their command of the English language, which was the required medium of instruction. The lack of proficiency in English among some of the teachers had affected their capability to teach the subjects in which they were qualified to do so. This state of affairs under the PPSMI had served to underscore the importance of teacher quality and how it could affect the implementation and goals of a language education policy.

In this paper, the issue of teacher quality was explored within the context of the new language education policy, the MBMMBI. Under this new policy, several strategies were put in place to facilitate the process of implementation. One of the strategies was to improve the quality of English language teachers. This strategy was examined in light of selected research findings and other information that were deemed relevant to a beneficial discussion of the topic. The discussion would include the issue of how quality features in the strategy and its sub-strategies as outlined in the policy booklet (MOE, n.d.a). The policy booklet was obtained from the ELTC-TED Conference 2011. In addition to this policy booklet, other related documents and resources providing supplementary information about the policy were also examined. The quality of teachers has frequently been linked to student achievement in schools (Goe, 2007; Goe \& Stickler, 2008). This important link between teacher quality and student achievement provides reason enough for a critical examination and discussion of the nature of inquiry conducted in this paper. It is also hoped that this paper would provide some impetus 
for further discussions of English language teacher quality in the current Malaysian educational context.

\section{DEFINING TEACHER QUALITY}

Various definitions of teacher quality can be found in the literature. As observed by Kennedy (2010), Goe (2007), and Mitchell, Robinson, Plake, and Knowles (2001), there was no common definition of teacher quality. Mitchell et. al. (2001) referred to teacher quality as the knowledge, skills, abilities and dispositions of teachers. Other authors, for instance, Lesley, Gee and Matthews (2010) provided a list of attributes in their definition of quality teachers, and these included the ability to embrace various roles such as problem solver, researcher, and collaborator within the school, the local educational context and the larger society.

Teacher quality is also usually defined as synonymous with teacher effectiveness or teaching quality. Teacher quality has been associated with various notions such as experience, expertise, knowledge, competence, training, and professional development. Mitchell et. al. (2001) traced the historical changes in the definitions of teacher quality over a century in America. The definitions ranged from concerns in teachers' moral conduct, personal traits, and technical skills, to the current definition based on standards which defined the knowledge, skills and dispositions that teachers should demonstrate. Cochran-Smith (2010) reported that the definitions of teacher quality found in the literature ranged from the straightforward and simple to the more complex ones. She concluded that no one definition seemed to be the right one as each was based on different agendas, purposes and the amount of teaching complexity it wished to capture. Based on their synthesis of research on teacher quality, Goe and Stickler (2008) categorised teacher quality indicators into four components labelled as teacher qualifications, practices, characteristics and effectiveness.

Teacher quality has been reported as an indicator of student achievement and gains (Goe, 2007). This relationship was seen as not limited to test scores alone. Tucker and Stronge (2005) stated 
that highly effective teachers had an enriching effect on their students' daily lives and lifelong educational and career goals. This statement was supported by a recent study by Chetty, Friedman, Hilger, Saez, Schanzenbach and Yagan (2011) who found that what the students achieved later in their lives could also be traced back to the quality of the teachers they had earlier in their lives. The results of the study by Chetty et al. in the United States showed that students taught by experienced teachers in a kindergarten had better adult outcomes, i.e., higher earnings, than those taught by less experienced teachers. According to Goe and Stickler (2008), even when teacher characteristics and teacher experience might not show obvious improvement in student achievement such as in tests, they might contribute to less obvious overall student achievement through their practices such as their collegiality, leadership ability and impact on the school culture.

In the Malaysian context, the current definition of teacher quality is based on the standards set by the Ministry of Education. Prior to the introduction of the MBMMBI policy, the previous PPSMI policy was focused on improving the quality of students' English language proficiency rather than teacher quality. However, towards the end of the policy period, teacher quality was already a concern as evidenced in the Malaysia Teacher Standards of 2009, which listed the professional competencies required of quality teachers. In order to produce teachers of quality, the training of teachers emphasised on the following three main aspects, namely the practice of professional teaching values, knowledge and understanding, and teaching and learning competence (BPG, 2009). In addition to the national Malaysia Teacher Standards which apply to all teachers, another set of standards specific for English language teaching was introduced in 2012. This set of standards named 'Pedagogy Standards for English Language Teaching' (PSELT) became an important tool used to measure the quality of English language teaching among teachers at different stages of their career and to guide the training and professional development of those teachers (Yeow, 2012). Based on this set of standards, teachers of quality have been defined as possessing pedagogical competence and mastery of the English language (MOE, 2012a). 


\section{METHODOLOGY}

The method employed was document analysis, which involved the intensive reading of all the documents selected. Documents are a rich source of data and are easily accessible (Punch, 1998). The original MBMMBI policy booklet (MOE, n.d.a) was the 'anchor' document used in the analysis. The printed copy of the policy booklet was obtained from the ELTC-TED Conference 2011 but an electronic copy was also available online for public access.

Although the policy is concerned with Bahasa Malaysia and the English language, the analysis in this study was focused on content related to the English language. This focus was maintained when searching for and examining other documents about the MBMMBI policy, including documents providing supplementary information about it, and documents reporting on information related to its strategies. The quality of English language teachers was the key focus and analytical theme.

Most of the documents selected were published by the Ministry of Education. Two documents were prepared by the Performance Management and Delivery Unit (PEMANDU) and one was from the British Council. All the documents were accessible to the public in the Internet.

\section{IMPROVING THE QUALITY OF ENGLISH LANGUAGE TEACHERS: THE MBMMBI STRATEGY}

Eight strategies were outlined under the MBMMBI policy for both the national language (Bahasa Malaysia) and English (MOE, n.d.a). In its efforts to strengthen the English language, four strategies have been put in place and implemented (MOE, n.d.a, p. 2) as follows:

- Increasing the number of hours for teaching and learning of English in SMK (Sekolah Menengah Kebangsaan, National Secondary Schools), SK (Sekolah Kebangsaan, National Schools), SJK(C) (Sekolah Jenis Kebangsaan (Cina), National-type School (Chinese)) and SJK(T) (Sekolah Jenis Kebangsaan (Tamil), National-type School (Tamil)).

- $\quad$ English language teachers of quality. 
- The teaching and learning approach.

- Expanding the functions of computer laboratories to language labs.

These strategies are as shown in diagrammatic form in Figure 1.

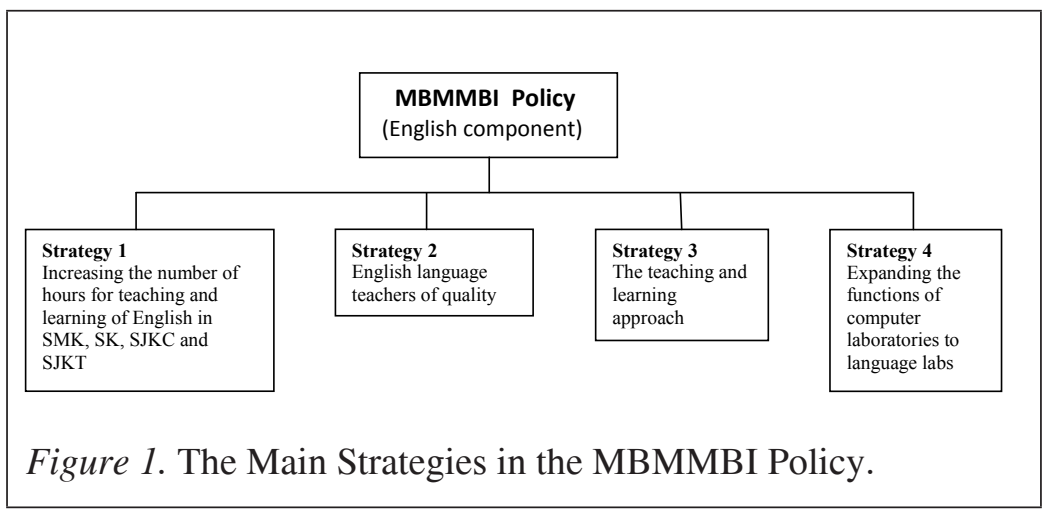

'SK' as stated in the first strategy stands for 'Sekolah Kebangsaan' and 'SM' for 'Sekolah Menengah', which refer to the national primary and secondary schools in Malaysia respectively. The medium of instruction in national schools is Bahasa Malaysia, the Malay/national language. 'SJK' refers to national type schools in which the vernacular language, either Chinese (C) or Tamil (T) is used as the medium of instruction.

It is evident that teachers feature directly and prominently in the second strategy, the focus of this paper, and indirectly in the first and third strategy. In the introductory pages of the policy booklet (MOE, n.d.a), it is clear that the second strategy points to teacher quality as a means of strengthening the teaching and learning of the English language, which it is hoped will, in turn strengthen the command of the English language among students in the education system.

An elaboration of this second strategy (to be referred to as the "main strategy' after this) reads as follows:

Teachers who teach this subject must be Englishoptioned to ensure quality from the pedagogical aspect. Teachers will be encouraged to attend courses to enhance their professionalism and to learn about the 
latest development about the areas of language and pedagogy from local and foreign experts. 376 native English speaking teachers will be recruited to train our local teachers at specific Teacher Training Institutes and selected schools. The MOE will also recruit 600 retired English teachers to teach in schools. MOE will also increase the intake of English language teachers (MOE, n.d.a, p. 13).

The main strategy as spelt out above by the MOE can be unpacked as comprising the following five sub-strategies:

- ensuring that teachers teaching the subject are Englishoptioned in order to assure quality from the pedagogical aspect

- encouraging teachers to attend courses to enhance their professionalism and to learn about the latest development about language and pedagogy from local and foreign experts

- $\quad$ recruiting 376 native English speaking teachers to train local teachers at specific Teacher Training Institutes and selected schools

- $\quad$ recruiting 600 retired English language teachers to teach in schools

- $\quad$ increasing the intake of English language teachers

Teachers who are English-optioned normally possess a qualification such as a diploma or/and degree in teaching English as a second language or a related field such as English literature or linguistics. Non-English-optioned teachers who teach English possess qualifications in other areas of specialisation which are not related to English such as history, science, and mathematics.

The first four sub-strategies are explained in more detail in a more recent information booklet containing the strategies for implementing the MBMMBI policy (MOE, 2014). The fifth substrategy, however, was not mentioned in the booklet.

\section{DISCUSSION}

In this section, the discussion will be structured according to the five sub-strategies of the MBMMBI policy for English as listed in the previous section. The discussion is focused on the aspects and 
issues of quality as outlined in the official documentation for each sub-strategy.

The inclusion of a strategy that focuses on teacher quality in the Malaysian educational policy is a welcome move in an education system that is beginning to ease its heavy reliance on examinations to assess student learning. Teacher quality not only has an effect on how much students learn but also has a lasting effect on student achievement (Tucker \& Stronge, 2005). Stronge (2006) stated that the essential issue was that we had the most effective teachers possible guiding the learning of students. The policy strategy specified as 'English language teachers of quality' has several substrategies focused on improving teacher knowledge, evaluating and monitoring teacher knowledge and practices, improving teacher pedagogical knowledge, and increasing the number of English language teachers. Quality constantly features in the strategies and is focused on improving, evaluating and monitoring teacher knowledge and practices. However, it is not clear whether quality is a feature in the strategies focused on increasing the number of English language teachers.

\section{First Sub-strategy: English-optioned Teachers}

The first sub-strategy is often found in the literature and is regarded as an important indicator of quality teachers. The notion of quality of concern here refers to the teacher's subject qualification. Here, it is clearly spelt out that teachers must be English-optioned. Teachers of English must possess the relevant formal qualifications in an English related field, usually Teaching of English as a Second Language (TESL), English Literature, Linguistics, or other areas of study related to the English language such as English Communication. The formal qualifications in these areas of study would usually have been obtained at the diploma or degree levels.

This first sub-strategy is the right step forward. There are many English language teachers in the Malaysian education system who are not English-optioned, but have been given the responsibility to teach English mainly due to the shortage of English-optioned teachers in some schools. The programme carried out under this first sub-strategy involved relocating English-optioned teachers. 
When certain areas had an excess of English-optioned teachers, they would be relocated in under-served schools (MOE, 2014). The redeployment of English-optioned teachers might help to solve the problem of the shortage of qualified teachers to teach English, but the issue of teacher quality was not necessarily solved. Being English-optioned would at the very least ensure that teachers have the appropriate subject-matter knowledge which is crucial for teachers teaching any subject. Deep understanding of subject matter is important for pedagogical content knowledge (Grossman, Schoenfeld \& Lee, 2005). Reports in the literature have confirmed that knowledge of a subject contributes to or influences how it will be taught (e.g., Andrews \& McNeill, 2005). A cautionary note worth mentioning here, however, is that being English-optioned alone does not necessarily guarantee a teacher of quality. Being highly qualified on paper does not guarantee that teachers are effective in their classrooms (Goe, 2007). A study by the Higher Education Leadership Academy (AKEPT) found that the teachers in its study were focused more on achieving surface level understanding of content rather than cultivating higher order thinking skills in learners (MOE, 2015). Some studies on worker effectiveness have revealed that cognitive ability is a powerful predictor of effectiveness (Harris $\&$ Rutledge, 2007). The quality of the qualifications possessed by the teacher should also be considered.

\section{Second Sub-strategy: Teacher Professionalism}

The second sub-strategy involves teacher professionalism. Teachers are encouraged to attend courses for two main purposes: enhancing their professionalism and their learning about the latest development about language and pedagogy from local and foreign experts. According to Eraut (1994), bringing practicing professionals into contact with new knowledge and ideas is a central purpose of continuing professional education, and the second sub-strategy serves this purpose.

With the introduction of the MBMMBI policy, various training programmes have been carried out for both pre-service and inservice teachers. Many new courses appeared on the scene, among which were courses that would train teachers involved in the implementation of the new curriculum and courses to improve the 
proficiency levels, content knowledge and pedagogical skills of both optionist and non-optionist teachers (MOE, n.d.b, 2013; 2014). The variety of courses catered to the training needs of both groups of teachers as identified by the ministry or the teachers themselves. English teachers were required to take the Cambridge Proficiency Test and based on the results of the test, teachers needing remedial training would have to undergo the Professional Upskilling for English Language Teachers (ProELT) course (PEMANDU, 2015). Teachers could also identify their own professional training needs after using the PSELT online self-evaluation instrument and then apply for relevant courses to meet those needs (MOE, 2012b).

The support for the development of teacher professionalism is a recognition of the need for teachers to develop professionally on a continuous or life-long basis. Goe and Stickler (2008) stated that good professional development may help teachers to manage the classroom and student behaviour, learn new ways of teaching a subject, and understand how much students have learned and what additional learning do they need. As long as the length, content, and training approaches have been carefully considered, the various courses made available to the teachers would be beneficial for them. Otherwise, the impact on the teachers would be minimal or not long-lasting. There is ample evidence in the literature showing that the length of teacher training courses can either be effective or not effective for teachers. Montgomery (2002) stated that one-day or short training courses were not effective in promoting changes in practice or teaching behaviour. In support of the findings in Montgomery (2002), Wahlgren and Larsen (2009) through their review of the literature on the impact of teacher training for teaching adult learners also showed that intensive and sustained training programmes were more likely to lead to significant professional growth or change.

An example of how training approaches could affect teacher quality was obtained from a study by Napisah Kepol, Mariyatunnitha Shari, and Nadiah Yan Abdullah (2012), in which it was shown that the train-the-trainer model which was used to train teachers implementing the new English curriculum for primary schools in Malaysia was problematic. This approach involved ministrytrained master trainers providing training to heads of English 
panels or selected teachers, who in turn had to train the teachers in their respective schools. While this approach might be a way of managing the logistics of providing curricular and pedagogical training nationwide, it also meant that there were teachers who received second-hand information about the training content when the training was subsequently provided in-house at their respective schools. There were also teachers who were left to their own resources and continued to teach based on their own interpretation of the curriculum while waiting for the in-house training or waiting for their turn to attend the training courses themselves. Alternative approaches to continuous professional development should be employed to ensure that the training programmes can reach and involve all teachers more efficiently and effectively.

Many of the training programmes provided under the MBMMBI policy as listed in the 2014 MBMMBI booklet (MOE, 2014) followed the traditional approach to professional development. This was rather surprising as there were other approaches described in the literature which might be able to provide more effective alternative approaches to the professional development of teachers in Malaysia. An alternative approach that had seen some success as reported in the literature was the professional learning communities model. This model assumed the idea that the learning and sharing of knowledge was promoted through collaborative collegial effort and that participation in professional learning communities would lead to changes in teaching practices and student learning (Caena, 2011). Research has provided evidence of the positive impact of this model on teaching practice and student learning (Vescio, Ross \& Adams, 2008).

Although not specifically a strategy under the MBMMBI policy, a move towards working in communities of practice in Malaysian schools was the School Improvement Specialist Coaches (SISC) programme which, like the MBMMBI policy, was initiated under the National Key Results Areas (NKRA) for education in the Government Transformation Programme (PEMANDU, 2012). This programme was aimed at narrowing the achievement gap between the lowest and highest performing schools and also at empowering the District Education Offices in their endeavour to improve student outcomes. In this programme which started in 2011 for the English 
Language, Bahasa Malaysia and Mathematics subjects, coaches were selected, usually from among recipients of the Excellent Teachers award, and were provided training as master coaches. These coaches would work with administrators and teachers in low performing schools to identify problems that were prevalent in these schools and then design intervention or remedial programmes to help solve the specific problems found in the each school. The coaches, however, were required to visit and monitor the schools under their charge only three times a year. A spin-off programme called the SISC+ programme required the selected coaches to be based full-time at the local district education departments and to monitor the schools under their charge four times a week.

Professional development and reflection should be a consistent feature of practice among teachers (Barber, 2005). On-site professional development requires professional communication and collaboration among teachers. Little (2002) stated three conditions for promoting professional communication and collaboration among teachers. The conditions were shared interests and shared responsibility (interdependence), opportunity, and resources. Little had also pointed out the important role of formal decision making at the school level, leadership and culture building that would help to ensure these conditions for teachers.

\section{Third Sub-strategy: Native Speaker Expert Programme}

The native speaker expert programme, which was the third substrategy, was implemented from 2011 to September 2015. Three companies were selected to participate in the programme (Borneo Post Online, 2014). The programme involved the deployment of three hundred and seventy-six native speaker (NS) English teachers to train local teachers at selected teacher training institutes and primary schools. Each of these native speaker teachers would work with several local teachers and schools to train and monitor the local teachers in their classrooms. They also conducted training workshops.

Although providing a new element of natural English language use and culture to the local teaching and learning environment, an issue of quality concerning this programme was the qualifications of the 
native speaker teachers selected for the programme. Being a native speaker did not necessarily mean that a teacher would be able to speak the language fluently or was skilled as a language teacher (Hall, 2012). Neither could a teacher with two or three years of teaching experience be considered an expert. Sophisticated expertise was gained through many years of experience (Bransford, DarlingHammond \& LePage, 2005). Appropriate and relevant qualifications and experiences were still needed, especially if a teacher was to mentor and train other teachers. If the MBMMBI policy aspired to have all local English language teachers English-optioned, then the same criteria should be imposed on other teachers or teacher trainers who were expected to mentor, train and monitor the local teachers. Furthermore, the native speakers' teaching experiences gained in a context different from Malaysia could turn out to be a disadvantage, as teaching and learning is always context-dependent. As their assignment for the job in the native speaker expert programme was specific to English language teaching in Malaysia, issues regarding cultural and contextual knowledge such as knowledge of the Malaysian educational system and the cultural background of the learners in the country should be sufficiently addressed. This was especially important in the context of native-speaker teachers who did not have any teaching experience in Malaysia, as they would be training teachers of children that they themselves had no prior experience teaching. Knowledge of learners and educational contexts have been issues of great concern in the literature on teacher knowledge ever since Shulman $(1986,1987)$ drew attention to the importance of understanding the teacher's knowledge base.

The British Council, one of the three agencies which participated in the programme, reported an improvement in the proficiency levels of the participating teachers as measured by the Common European Framework of Reference for Languages (CEFR) and changes in the teachers' attitude and practices (British Council, n.d.). Although this programme reported some success in improving the quality of teachers, it was limited to 6,500 primary school teachers in East and West Malaysia. If one-to-one mentoring, as the method used in the programme could indeed improve teacher quality, its feasibility for application with all the remaining teachers, both primary and secondary, in Malaysia should be explored, either with native speaker or non-native speaker experts as mentors. 


\section{Fourth and Fifth Sub-strategies: Increasing the Number of English Language Teachers}

The fourth and fifth sub-strategies involved increasing the number of English language teachers in the country's education system. These two sub-strategies would involve the recruitment of 600 retired English language teachers to teach in schools and increasing the intake of English language teachers respectively. It is unclear how quality would feature in the two sub-strategies, or how these sub-strategies would contribute to the main strategy.

The appointment of retired English-optioned teachers on a contract basis has helped to address the problem of the shortage of Englishoptioned teachers in schools (MOE, 2014). As has been pointed out earlier, being English-optioned was seen as an indicator of quality. This was made clear by the first sub-strategy which required that teachers teaching the English language be English-optioned. However, unless the selection of the retired teachers was guided by additional criteria that helped to define quality teachers, this fourth sub-strategy might not be able to contribute to achieving the goals of the main strategy. As explained earlier, experience did not necessarily equate to quality.

Likewise, increasing the intake of English language teachers (the fifth sub-strategy) would not also necessarily guarantee quality. Controlling quality with regard to this sub-strategy involved many factors. For example, it would have to start with the selection of the candidates that made up the intake for teacher training programmes. Then once the candidates were accepted into the programme, there would be many other factors that might affect the quality of the trainees at the end of the programme such, as personal and situational factors. For instance, the quality of the training programmes in itself would also affect the quality of experience and knowledge that the trainees had received, which therefore would affect the quality of the trainee output at the end of the programme. Although the fifth substrategy only mentioned the need to increase the intake of English language teachers, an examination of the recent information booklet on the MBMMBI policy would show that the issue of quality was recognised and was addressed through the provision of programmes focused on improving the competency of preservice teachers along with in-service teachers (MOE, 2014). 


\section{Teacher Disposition and Evaluation}

The five sub-strategies discussed so far point to the professional qualification and development of teachers, teacher exposure to nativespeaker expertise, and expansion of the English teacher workforce. Going back to the definition of teacher quality presented earlier in this paper, it is important to note that the first three sub-strategies have addressed the commonly included dimensions of knowledge, skills and abilities found in the definitions of teacher quality in the literature. The aspect concerning disposition of teachers, however, was not included in the main strategy. Issues concerning disposition such as attitude is worth considering as research has shown that teacher attitude affects classroom environment (OECD Report, 2009), teacher behavior (Ahmad \& Sahak, 2009) and student attitude (Denessen, Vos, Hasselman \& Louws, 2015). A teacher who is equipped with subject matter knowledge and pedagogical skills, but does not have the positive attitude expected of a good teacher may not be able to help achieve the aspirations of the MBMMBI policy. Attitude forms part of a teacher's character and improving the quality of teachers should extend to quality in character as well, and not just in practices or knowledge bases. Bransford, DarlingHammond and LePage (2005) pointed out that in addition to teacher knowledge and experience, there were many other attributes that mattered for teaching, such as enthusiasm, perseverance, flexibility and a concern for children.

Another aspect closely related to quality that was not mentioned in the main strategy was the evaluation of teachers. Stronge and Tucker (2003) as cited in Stronge (2006) stated that it was not possible to know if we had high quality teachers without having high quality evaluation systems. The Malaysian Ministry of Education has developed a new evaluation system to assess in-service teachers (MOE, 2013), but whether this system was appropriate and sufficient for evaluating the newly-defined quality English teachers remained to be seen. Tucker and Stronge (2005) suggested that student achievement should be used together with professional judgement about teacher qualifications and behaviours when implementing teacher evaluation. Professional judgement should be informed by the use of multiple data sources such as classroom observations, portfolios, and client surveys. 
Figure 2 shows the five existing sub-strategies stated under the second main strategy focused on improving the quality of English language teachers in the MBMMBI policy. Notice the inclusion of two sub-strategies in the boxes with the dotted lines showing the aspects which have not been included under the main strategy. These two potential sub-strategies, if added, would provide a more balanced approach to efforts at improving teacher quality.

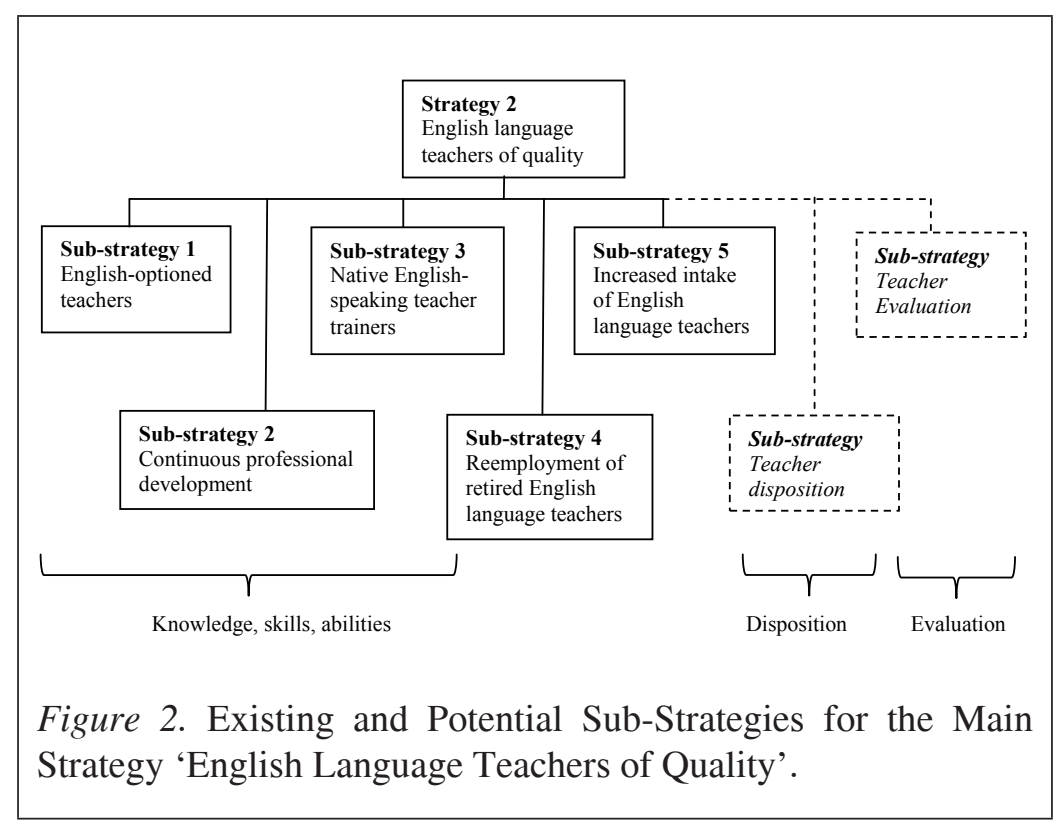

\section{CONCLUSION}

The examination of the strategies designed to produce English language teachers of quality in the MBMMBI policy has shown that quality has been directly and clearly featured in the first three substrategies and less so in the remaining two. The two criteria, namely pedagogical competence and mastery of the English language on which the definition of quality for Malaysian English language teachers was based, were referred to in the sub-strategies in different ways. While the first three sub-strategies will help teachers to achieve the two criteria by putting in the correct emphasis on knowledge and skills specifications or training in these aspects, the same cannot be said of the fourth and fifth sub-strategies. These latter two 
sub-strategies do not seem to fit well with the first three sub-strategies. This is because their focus is on the need to further increase the number of teachers in the teaching workforce by hiring retired teachers and new teachers. Quality should feature consistently in all the five sub-strategies under the main strategy. Aspiring for quality in only some of the strategies will create pockets of inconsistencies that will interfere with the aims of the policy.

It can also be concluded that by looking at the definition of quality teachers on the basis of pedagogical competence and mastery of the English language, the MBMMBI policy has not been able to capture the full complexity of the concept of teacher quality. In other words, the policy has not taken into consideration many other attributes of quality that a teacher should possess and demonstrate. Possession of a higher qualification, for example, constituted only one of the qualities of an effective teacher (Tucker \& Stronge, 2005). The literature review has shown that there was not only one attribute, but many attributes working together in tandem in a teacher that would lead to quality teaching in a subject. Perhaps dealing with only two attributes of teacher quality has made it more manageable for the policy makers, especially since the drive for teacher quality is at the early stages of implementation. Trying to ensure that all teachers develop and achieve the two attributes is not an easy task, but it is a necessary initial step towards fulfilling the aspirations of the policy. Another important step is for the policy makers to ensure that follow-up strategies such as monitoring, evaluation, reinforcement, and support strategies are continuously in place and implemented so that the policy in practice can have the desired effect as envisioned.

\section{ACKNOWLEDGEMENT}

An earlier unpublished version of this paper was presented at the $22^{\text {nd }}$ MELTA Conference in Johor Baharu on 28-30 May, 2013. The current version had been updated as part of the Niche Research Grant Scheme (NRGS) project entitled 'Development of a Teacher Education Model for Preparing Quality Teachers for the Future' (2014-2018), Code No. 2014-0001-107-82-7-3. 


\section{REFERENCES}

Ahmad, A. \& Sahak, R. (2009). Teacher-student attachment and teachers' attitudes towards Work. Jurnal Pendidik dan Pendidikan, 24, 55-72.

Andrews, S. \& McNeill, A. (2005). Knowledge about language and the 'Good language teacher'. In Bartels, N. (Ed.), Applied linguistics and language teacher education (pp. 159-178). New York: Springer Science+Business Media, Inc.

Bahagian Pendidikan Guru. (2009). Standard Guru Malaysia. Putrajaya: BPG.

Barber, M. (2005). National strategies for educational reforms: Lessons from the British experience since 1998. In Fullan, M. (Ed.), Fundamental change (pp. 73-97). Dordecht, The Netherlands: Springer.

Bransford, J., Darling-Hammond, L. \& LePage, P. (2005). Introduction. In Darling-Hammond, L. \& Bransford, J. (Eds.), Preparing teachers for a changing world (pp. 1-39). San Francisco, CA: Jossey-Bass.

British Council. (n.d.). The book of change. Retrieved from https:// www.britishcouncil.my/sites/default/files/the_book_of_change.pdf

Caena, F. (2011). Literature review: Quality in teachers' continuing professional development. European Commision. Retrieved from http://ec.europa.eu/education/policy/strategicframework/ doc/teacher-development_en.pdf

Chetty,R., Friedman, J. N., Hilger, N., Saez, E., Schanzenbach, D. W. \& Yagan, D. (2011). How does your kindergarten classroom affect your earnings? Evidence from Project Star, The Quarterly Journal of Economics, 126(4), 1593-1660. Retrieved from http://obs.rc.fas.harvard.edu/chetty/STAR.pdf Cochran-Smith, M. (2010). Foreword. In Kennedy, M. (Ed.), Teacher assessment and the quest for teacher quality: A handbook. San Francisco: John Wiley \& Sons. Retrieved from http://books.google.com.my/books

Denessen, E., Vos, N., Hasselman, F. \& Louws, M. (2015). The relationship between primary school teacher and student attitudes towards science and technology, Education Research International, Volume 2015, Article ID 534690. Retrieved from http://dx.doi.org/10.1155/2015/534690 
English native speaker mentoring programme improves proficiency of teachers. (2014, March 25). Borneo Post Online. Retrieved from http://www.theborneopost.com/2014/03/25/ englishnative-speaker-mentoring-programme-improves-proficiencyof-teachers/

Eraut, M. (1994). Developing professional knowledge and competence. London: Falmer Press.

Goe, L. (2007). Linking teacher quality and student outcomes. In Dwyer, C. A. (Ed.), America's challenge: Effective teachers for at-risk schools and students (pp. 7-24). Washington, D.C.: National Comprehensive Center for Teacher Quality. Retrieved from http://www.gtlcenter.org/sites/default/files/ docs/NCCTQBiennialReport.pdf

Goe, L. \& Stickler, L. M. (2008). Teacher quality and student achievement: Making the most of recent research. Washington, D.C.: National Comprehensive Center for Teacher Quality. Retrieved from http://files.eric.ed.gov/fulltext/ED520769.pdf Grossman, P., Schoenfeld, A., \& Lee, C. (2005). Teaching subject matter. In Darling-Hammond, L. \& Bransford, J. (Eds.), Preparing teachers for a changing world (pp. 201-231). San Francisco, CA: Jossey-Bass.

Hall, S. J. (2012). Deconstructing aspects of native speakerism: Reflections from in-service teacher education, The Journal of Asia TEFL, 9(3), 107-130. Retrieved from www.asiatefl.org.

Harris, D. N. \& Rutledge, S. A. (2007). Models and predictors of teacher effectiveness: A review of the literature with lessons from (and for) other occupations. Retrieved from http://www. teacherqualityresearch.org/models.pdf.

Kennedy, M. M. (2010). Attribution error and the quest for teacher quality. Educational Researcher, 39(8), 591-598. doi: 10.3102/0013189X10390804

Little, J. W. (2002). Professional communication and collaboration. In Hawley, W. D. with Rollie, D. L. (Eds.), The keys to effective schools (pp. 43-55). Thousand Oaks, CA: Corwin Press, Inc.

Lesley, M., Gee, D. \& Matthews, M. (2010). Separating the chaff of bureaucracy from the grain of pedagogy. Teacher Education Quarterly, Spring 2010. Retrieved from http://files.eric. ed.gov/fulltext/EJ896069.pdf 
Ministry of Education (MOE) (a). (n.d.a). To uphold Bahasa Malaysia \& to strengthen the English language - Booklet. Also available online at http://www.moe.gov.my/ mbmmbi/ moe_mbmmbi_03.htm.

Ministry of Education, Malaysia (MOE). (n.d.b). Program peningkatan profesionalisme guru Bahasa Inggeris. Retrieved from https://nkra.moe.gov.my/doc/dokumen/Pembentangan Program PeningkatanProfesionalismeGuruBI_5.9.12.pdf

Ministry of Education, Malaysia (MOE). (2012a). Taklimat pelaksanaan analisis keperluan latihan Pegawai Perkhidmatan Pendidikan Bahasa Inggeris (PPI BI) 2012 kepada sekolah. Retrieved from http://www.moe.gov.my

Ministry of Education, Malaysia (MOE). (2012b). Ministry of Education policies: Frequently asked questions. PowerPoint Presentation. Retrieved from http://www.kpkk.gov.my /pdf/ Dasar-dasar\%20KPM\% 20(BI)\%20(NCM).pdf

Ministry of Education, Malaysia (MOE). (2013). Malaysia Education Blueprint 2013-2025.

Putrajaya: Ministry of Education, Malaysia. Retrieved from http://www.moe.gov.my/cms/upload_files/articlefile/2013/ articlefile_file_003108.pdf

Ministry of Education, Malaysia (MOE). (2014). Dasar Memartabatkan Bahasa Malaysia Memperkukuhkan Bahasa Inggeris. Putrajaya: Ministry of Education, Malaysia. Retrieved from http://www.moe.gov.my/cms/upload_files/ articlefile/2015/articlefile_file_003767.pdf

Ministry of Education, Malaysia (MOE). (2015). Malaysia education for all: End decade review report 2000-2015. Putrajaya: Ministry of Education. Retrieved from http://www.moe. gov.my/cms/upload_files/files/KPM\%20\%20Malaysia\%20 Education\%20For\%20All\%20 (End\%20Decade\%20Review\% 20Report).pdf

Mitchell, K. J., Robinson, D. Z., Plake, B. S. \& Knowles, K. T. (2001). Testing teacher candidates: The role of licensure tests in improving teacher quality. Washington, DC: National Academy Press.

Montgomery, D. (2002). Helping teachers develop through classroom observation (2nd ed.). London: David Fulton Publishers. 
Napisah Kepol, Mariyatunnitha Shari, \& Nadiah Yan Abdullah. (2012, October). Curriculum change:ESL teachers' understanding and challenges. Paper presented at the Asian Conference on Education 2012, Osaka, Japan. Unpublished.

Performance Management and Delivery Unit (PEMANDU). (2012). Government transformation programme: Annual report 2012. Putrajaya: PEMANDU. Retrieved from http:// www.pemandu.gov.my/gtp/annualreport2012/NKRAs-@ improving_Students_Outcomes.aspx

Performance Management and Delivery Unit (PEMANDU). (2015). Government Transformation Programme: 2014 annual report. Putrajaya: PEMANDU. Retrieved from http:// www.pemandu.gov.my/gtp/annualreport2014/upload/file/ GTP_AR2014.pdf

Punch, K. F. (1998). Introduction to social research. London: SAGE Publications.

OECD. (2009). Creating effective teaching and learning environments: First results from TALIS. OECD Publishing. Retrieved from http://www.oecd.org/edu/school/4302 3606.pdf.

Shulman, L. S. (1986). Those who understand: Knowledge growth in teaching, Educational Researcher, 15(5), 4-14.

Shulman, L. S. (1987). Knowledge and teaching: Foundations of the new reform, Harvard Educational Review, 57, 1-22.

Stronge, J. H. (2006). Teacher evaluation and school improvement. In Stronge, J. H. (Ed.), Evaluating teaching (2nd ed.), 1-23. Thousand Oaks, CA: Corwin Press.

Tucker, P. D. \& Stronge, J. H. (2005). Linking teacher evaluation and student learning. Alexandria, Virginia: Association for Supervision and Curriculum Development.

Vescio, V., Ross, D. \& Adams, A. (2008). A review of research on the impact of professional learning communities on teacher practice and student learning, Teaching and Teacher Education, 24, 80-91. Retrieved from http://www.k12.wa.us/ Compensation /pubdocs /Vescio2008PLC-paper.pdf

Wahlgren, B. (n.d.). What impact does teacher training have on the student's performance? Retrieved from http://ncfk.dpu.dk/ fileadmin/nck/Nyheder/ASEMartikel_maj_2012.pdf

Wahlgren, B. \& Larsen, L. L. (2009). Teachers and trainers in adult education and lifelong learning. Retrieved from http://www. die-bonn.de/asem/asem0919.pdf 
Yeow, P. W. (2012, October). Standards, challenges and guidelines: Setting pedagogy standards for English language teachers (PSELT): A Malaysian case study. PowerPoint presentation presented at the IATEFL AMATE Conference. Retrieved from http://tea.iatefl.org/Prague2012/Standards,Challenges $\% 20$ \&\%20Guidelines-Yeow.pdf 